\title{
DISABILITY INSURANCE: INTERPRETATION OF CONFINEMENT CLAUSES
}

$T$ HE FREQUENTLY-LITIGATED ${ }^{1}$ confinement clause incorporated into most $^{2}$ sickness and accident disability insurance policies was the subject of a recent case, Suits v. Old Equity Life Ins. Co. ${ }^{3}$ A paraplegic sued for payments withheld under the following provision of his policy:4 If the injury or sickness confines the insured continuously within doors . . . and requires regular treatments therein by a legally qualified physician ... the Company will pay benefits . . . so long as such confinement remains continuous, provided said injury or sickness causes total disability . . . .

The defendent-insurer, though not contesting disability, ${ }^{5}$ contended that the confinement requirement had not been satisfied. Although the plaintiff was severely restricted in his activities, he was, among other things, away from his home for hours at a time and commuted for two years in his specially-equipped automobile to a university thirtyfive miles distant. The North Carolina Supreme Court reasoned that the confinement provision, being a contract term, could not be ignored, and "reluctantly" concluded that the plaintiff's activities had been "too extensive and too regularly carried on for too long a time to permit him to qualify for benefits under the confinement provision of the policy."'

Insurers insert confinement clauses in disability policies primarily because of the difficulty in ascertaining whether a claimant is actually disabled. ${ }^{7}$ The rationale is that the confinement requirement provides

\footnotetext{
${ }^{1}$ Cases are collected at Annot., 29 A.L.R.2d 1408 (1953). See also, 7 Couch, INSURANCE $\$ \S 1678-79$ (1930).

${ }^{2}$ See Adelman, Confining Clauses in Loss-of-Time Contracts, 1958 INs. L.J. 154. Virtually all of the disability policies on file with the North Carolina Insurance Commission require confinement to recover sickness benefits. Most of them also have the same requirement for accident benefits.

3249 N.C. 383 , 106 S.E.2d 579 (1959).

11 . at 383 , 106 S.E.2d at 580 .

-1d. at 384 , 106 S.E.2d at 581 .

'1d. at 386,106 S.E.2d at 581 . It should be noted that the court also relied upon the fact that the policy contained a nonconfinement clause. See notes $I_{3}$ and $I_{4}$ and accompanying text, infra.

"These clauses are variously worded. The insured's sickness or injury, to make him eligible for benefits, or at least full benefits, must be such as to " confine [him] to the house,' the word 'confine' generally being preceded by some or all such qualifications as 'necessarily,' 'continuously,' 'strictly,' and 'absolutely'; and the words 'to the house' being frequently replaced by 'within doors,' 'within the house,' or 'in the house,' or still
} 
a sufficiently objective determinant of disability. Because confinement is generally onerous, the clause also seems to discourage fraudulent claims. $^{8}$

There are three basic approaches to the problem. ${ }^{9}$ Some courts favor literal interpretation of the confinement provision, and require that the insured be confined in the plain, ordinary sense of the word. ${ }^{10}$ Two principal arguments are adduced: The greatest social value lies in protecting insurance funds from malingerers; ${ }^{11}$ and, the clause is an unambiguous contract term which no court should disregard. ${ }^{12}$ More-

other variations." Annot., 29 A.L.R.2d 1408, 14 II (1953). Differences in form are usually disregarded. But see, Cooper v. Phoenix Acc. \& Sick Benefit Ass'n, 14r Mich. 478, I 04 N.W. 734 (1905); Scales v. Masonic Protective Ass'n, 70 N.H. 490, 48 Atl. 1084 (I901).

Some clauses require confinement to bed. The insured is also usually required to receive regular treatments at the place of confinement by a qualified physician. Neither of these provisions is given much effect by the courts. Couch, op. cit. supra note 1 , at $\$ \$ 1679,168 \mathrm{I}$. In fact, the policy in the instant case included a "treatment therein" clause. The court disregarded the clause, however.

'Disability is not a sharply definable condition. Its commencement and termination are rarely susceptible to exact and absolute determination. The character of the applicant often outweighs his physical condition. Disability insurance losses are affected by many factors including age, sex, earnings, education, environment, heredity, residence, occupation, physical condition, general economic conditions and numerous psychological considerations-many of which are not clearly understood even by the psychologists themselves." MCCAHAN, ACCIDENT AND Sickness Insurance 3 (1954).

${ }^{8}$ Dunning v. Massachusetts Mut. Acc. Ass'n, 99 Me. 390, 59 Atl. 535 (1904); Mutual Benefit Health \& Acc. Ass'n v. Milder, I 52 Neb. 519,41 N.W.2d 780 (1950); Reeves v. Midland Cas. Co., I7० Wis. 370, I74 N.W. 475 (1919), reh. denied, I70 Wis. 378,174 N.W. 959 (1920).

Development of the law in this field has been little less than chaotic. Decisions are scattered all along the scale of interpretations, even in the same jurisdiction. For example, note the Missouri cases in Annot., 29 A.L.R.2d I408 (I953). The strong pull between orthodox contract principles and the sometimes emotive spectacle of crippled and sick claimants can be held partly accountable. Furthermore, the' judge's social philosophy can have great effect in this area. One court intimates, however, that the conflict is only apparent and that the approach taken, whether' strict or liberal, depends on whether the court doubts that the policyholder is disabled. Occidental Life Ins. Co. v. Bocock, 77 Ariz. 51, 266 P.2d I082 (I954). Assignment of most cases to one of the discernible categories is therefore arbitrary at best. Perhaps the only safe statement is that some courts are more willing than others to lessen the effect of the clause.

${ }^{10}$ See Goldsby v. Gulf Life Ins. Co., II 7 Fla. 889 , I58 So. 502 (1935); State $e x$ rel. Commonwealth Cas. Co. v. Cox, 322 Mo. 38, I4 S.W.2d 600 (1929).

${ }^{11}$ See cases cited note 8 sutpra.

${ }^{12}$ See Clesi v. National Life \& Acc. Ins. Co., I95 La. 736, I97 So. 413 (1940); Rocci v. Massachusetts Acc. Co., 222 Mass. 336, 110 N.E. 972 (1916), aff'd, 226 Mass. 545, 116 N.E. 477 (1917); Cooper v. Phoenix Acc. \& Sick Benefit Ass'n, 14r Mich. 478,104 N.W. 734 (rgo5). 
over, policies frequently provide reduced benefits for nonconfining disability. ${ }^{13}$ This fosters the contention that liberal interpretation of the confinement provision will nullify the nonconfinement clause. ${ }^{14}$

Because literal interpretation of confinement provisions often leads to inequitable results, ${ }^{15}$ even the most conservative courts have adopted a so-called "reasonable" approach to the problem. ${ }^{16}$

${ }^{13}$ The nonconfinement clause involved in the instant case provided for a monthly benefit of twenty-five dollars, not to exceed one month, in the event the policyholder was disabled and nonconfined. There are numerous other versions. Usually the amount payable is fifty per cent of the confinement benefit. The duration of payments may be the same as, or much less than, that for confinement. E. J. Faulkner, President of the Woodman Central Life Insurance Co., reports that the trend is toward elimination of the distinction between the two clauses on short term policies. McCaHAN, op. cit. supra note 7 , at 28 . A search through the sickness and accident insurance forms on file with the North Carolina Insurance Commission discloses, however, that no policy providing for lifetime sickness indemnity is without the nonconfinement clause.

${ }^{14}$ The instant case employed this reasoning. 249 N.C. at 386 , 106 S.E.2d at 582 . See, Sheets v. Farmers' \& Merchants' Mut. Life \& Cas. Ass'n, 116 Kan. 356, 225 Pac. 929 (1924); Rocci v. Massachusetts Acc. Co., 222 Mass. 336, 110 N.E. 972 (1916), aff'd, 226 Mass. 545, I16 N.E. 477 (1917). It can be concluded with formidable logic that the nonconfinement clause offers a good compromise solution which necessarily calls for a narrower construction of confinement. But, one can contend just as cogently that those nonconfinement clauses which allow only scant benefits cannot be dignified as a compromise solution. See, e.g., Harris v. Old Equity Ins. Co., 6I N.M. 261, 298 P.2d 943 (1956). In Brandt v. Mutual Benefit Health \& Acc. Ass'n, 30 Tenn. App. 14, 202 S.W.2d 827 (1947), the court forthrightly ruled that a nonconfinement clause should not affect the confinement provision. Many courts which are disposed to granting recovery do not bring up this problem.

A secondary clause is, indeed, a good way to adjust benefit payments to the seriousness of a claimant's condition. It is submitted, however, that confinement or nonconfinement is not the proper issue; rather, it should be total disability or partial disability for reasons made clear later in the text. The increased likelihood of fraud created by such a clause would be balanced by the limited liability.

${ }^{15}$ See, e.g., Mutual Benefit Health \& Acc. Ass'n v. Cohen, 194 F.2d 232 (8th Cir.), cert. denied, 343 U.S. 965 (1952); Lachterman v. Mutual Benefit Health \& Acc. Ass'n, 6o S.W.2d 646 (Mo. App. 1933); Reeves v. Midland Cas. Co., 170 Wis. 370, 174 N.W. 475 (I919).

${ }^{16}$ Obviously, confinement is not to be considered broken if the claimant has been forced out by such as fire, natural calamity, or legal order. See Mutual Benefit Health \& Acc. Ass'n v. McDonald, 73 Colo. 308, 215 Pac. 135 (1923). Nor is confinement broken by transfer from one place of confinement to another, short trips of medical necessity, or short periods in the fresh air. Williamson v. Nurses' Mut. Protective Corp., I42 Fla. 225, 194 So. 643 (I940); Bankson v. Mutual Benefit Health \& Acc. Ass'n, 208 La. 1008, 24 So. 2d 59 (1945); Ramsey v. General Acc., Fire, \& Life Ins. Co., 160 Mo. App. 236, 142 S.W. 763 (1912). Many policies now specifically permit trips to a doctor for treatments. No cases have been found in which a court has refused to accept confinement to a hospital as satisfaction of the policy. There is a split of authority, however, whether confinement to the grounds of a mental institution is sufficient. See Donlen v. Fidelity \& Cas. Co., II 7 Misc. 414, 192 N.Y. Supp. 513 (192I); Buske v. Federal Cas. Co., 200 Wis. I8, 227 N.W. 239 (1929). For other examples of "reasonable" construction, see Massachusetts Protective Ass'n v. Pickard, 76 F.2d 
A majority of the courts construe confinement provisions liberally. They treat confinement as a flexible word of art, ${ }^{17}$ which is satisfied if the claimant is "substantially" confined" ${ }^{18}$ or is required to spend "most" of his time indoors. ${ }^{19}$ Therapeutic absence is excused on the ground that curing the claimant is a paramount interest of all the parties. ${ }^{20}$ This liberal approach to the problem is flexible enough to achieve a laudable amelioration of the harshness associated with literal interpretation. In fact, many of these courts have so diluted the clause that it has been effectively eliminated-particularly through the therapeuticabsence exception. ${ }^{21}$ Generally, though, it is held that the provision cannot be totally expunged, and that there must be some significant degree of confinement. ${ }^{22}$

There are definite disadvantages in this approach to the problem. The real bases for decision-the conduciveness of a situation to malingering, the insurers' need for protection from certain types of borderline infirmities, ${ }^{23}$ the needs of claimants, and the social role of disability insurance-are often glossed over by the vague conclusion that there is insufficient confinement. Consequently, most decisions are more concerned with the metaphysics of confinement than with basic issues.

684 (5th Cir.), reh. denied, 77 F.2d 1006, cert. denied, 296 U.S. 598 (1935); Carabelli v. Mountain States Life Ins. Co., 8 Cal. App. 2d I15, 46 P.2d roo4 (I935); Mutual Benefit Health \& Acc. Ass'n v. Milder, 52 Neb. 5 19, 4x N.W.2d 780 (1950).

${ }^{27}$ The term is considered "ambiguous." As such it must be subjected to judicial interpretation. See, e.g., National Acc. \& Health Ins. Co. v. Mergenov, 49 Ohio App. 353 , 97 N.E. 248 ( 1935 ).

${ }^{18}$ See Penrose v. Commercial Travelers Ins. Co., 75 Idaho 524, 275 P.2d 969 (1954); Purcell v. Washington Fid. Nat'l Ins. Co., I46 Ore. 475, 30 P.2d 742 (1934).

${ }^{10} \mathrm{See}$ Hoffman v. Michigan Home \& Hosp. Ass'n, 128 Mich. 323, 87 N.W. 265 (rgor); World Ins. Co. v. McKenzie, 2 I2 Miss. 809, 55 So. 2d 462 (195 r).

${ }^{20}$ Columbian Relief Fund Ass'n v. Gross, 25 Ind. App. $2 \times 5,57$ N.E. 145 (1900).

${ }^{21}$ Conceivably, any conduct which a doctor may say is good for a patient can be considered therapeutic. For examples of what the courts have accepted as therapeutic treatment, see Mutual Benefit Health \& Acc. Ass'n v. Murphy, 209 Ark. 945, x 93 S.W.2d 305 (I946); Mutual Benefit Health \& Acc. Ass'n v. Burrow's Ex'rx, 257 Ky. 808, 79 S.W.2d ( 1934 ). But see, Franklin Life Ins. Co. v. Strength, 58 So. 2 d I 26 (Ala. App. 195 I), cert. denied, 257 Ala. 167,58 So. 2 d 129 (195I).

${ }^{32}$ Purcell v. Washington Fid. Nat'l Ins. Co., 146 Ore. 475,30 P.2d 742 (1934). In Wade v. Mutual Benefit Health \& Acc. Ass'n, II5 W. Va. 694, 698, I77 S.E. 6ri, $6 \times_{4}$ (1934), the decision called for a "practical and intelligent 'staying in,' the nature of the illness considered."

${ }^{23}$ A judicial record of leniency toward nonconfinement in connection with common sickness of indefinite seriousness might result in a great expansion of insurer liability which could not be borne by the industry. Thus, a court must be more cautious in dealing with, for example, mental disease or geriatric ailments than with Parkinson's disease. 
More important, this approach establishes a line beyond which relief is denied to genuinely disabled policyholders if they are not confined.

An increasing number of courts have attempted to resolve these problems by abrogating the confinement clause. ${ }^{24}$ Recognizing that the purpose of disability insurance is income protection, these courts regard the extent of confinement as merely evidence that the claimant's injury or illness has rendered his economic position such that indemnification by the insurer is warranted. In some jurisdictions this means that, to become eligible for benefits, a claimant must prove "disability"; ${ }^{25}$ in others, he must show that the "character and extent" of his "sickness" are sufficiently severe. ${ }^{26}$ In reality, these requirements are the same. ${ }^{27}$ In either case a high degree of confinement will improve the possibility of recovery, but nonconfinement alone will not bar it.

The strongest countervailing consideration is that the injustices wrought by the confinement requirement are infrequent and are ultimately justified by the increased security provided the insurance companies. It has been suggested that to deny this protection to insurers would raise premiums beyond the reach of those people who most need insurance. $^{28}$ On the other hand, it can be safely asserted that injustices are not occasional. While there is some correlation between actual inability to earn and confinement, the connection is not always present. ${ }^{20}$

\footnotetext{
${ }^{24}$ Not all of these courts are so bold in disregarding the clause as was the court in American Cas. Co. v. Horton, 152 S.W.2d 395 (Tex. Civ. App. 1941). See, e.g., Occidental Life Ins. Co. v. Bocock, 77 Ariz. 51, 266 P.2d 1082 (1954). See also, note 26 infra.

${ }^{25}$ Federal Sur. Co. v. Waite, 297 S.W. 312 (Tex. Civ. App. 1927); American Cas. Co. v. Horton, 152 S.W.2d 395 (Tex. Civ. App. 194I); Massachusetts Bonding \& Ins. Co. v. Springston, 283 P.2d 819 (Okla. 1955). Establishing legal disability properly calls into account such basic issues as those enumerated previously in the text. See note 23 supra and accompanying text.

${ }^{20}$ Many courts which follow this reasoning would not admit overthrowing the clause. Indeed, some cases, e.g., Mutual Benefit Health \& Acc. Ass'n v. McDonald, 73 Colo. 308, 215 Pac. 135 (1923), definitely demand a high degree of confinement. A somewhat more liberal viewpoint is adopted in Wade v. Mutual Benefit Health \& Acc. Ass'n, II5 W. Va. 694, I77 S.E. 6II (1934). A study of the cases, however, indicates that most courts following this view pay only lip service to the confinement requirement. Where the claimant is thought worthy, his sickness will usually be adjudged severe enough to excuse a great deal of nonconfinement. Thus, in Glenn v. Gate City Life Ins. Co., 220 N.C. 672 , 18 S.E.2d $113(1942)$, recovery was allowed despite nearly total lack of confinement.

${ }^{27}$ It has been recognized that the degree of sickness demanded by the latter school seems to be that which is serious enough to be disabling. Adelman, supra note 5, at $16 \mathrm{r}$.

${ }^{28} I d$. at 166.

${ }^{30}$ This is clearly borne out by cases such as the instant one, where disability was never in issue. This case also aptly illustrates the impact of new devices and trentments upon old notions about the correlation between disability and confinement.
} 
Further sympathy is evoked for the policyholder by the suspicion that the policy is often sold, as protection "for when you can't work," by a salesman who does not appreciate the legal implications of the confinement provision. ${ }^{30}$

Moreover, insurers do not need the protection a literal interpretation of the confinement clause provides. Courts can often detect malingerers by utilizing modern procedural devices for discovering and presenting medical evidence and by demanding a degree of proof in each case commensurate with its susceptibility to fraud. As to those policies demanding confinement even for accident disability, it should be noted that the accident itself is some evidence of the claim's authenticity. Finally, in jurisdictions employing liberal construction, the clause has already been drastically limited ${ }^{31}$ with no severe consequences. In these jurisdictions complete abrogation of the confinement requirement would create little additional opportunity for fraud and would foster the equitable adjustment of claims.

Prior to the Suits case North Carolina was firmly committed to the rule in which confinement is merely evidence of the "character and extent of sickness." 32 The North Carolina Supreme Court has unwisely repudiated that forward-looking, adaptable doctrine. ${ }^{33}$

${ }^{80}$ Mackprang v. National Cas. Co., 127 Neb. 877, 257 N.W. 248 (x934); Federal Sur. Co. v. Waite, 297 S.W. 312 (Tex. Civ. App. 1927).

${ }^{81}$ See notes $\mathrm{I}$-21 supra and accompanying text.

${ }^{32}$ Glenn v. Gate City Life Ins. Co., 220 N.C. 672, 18 S.E.2d 113 (1942); Thompson v. Mutual Benefit Health \& Acc. Ass'n, 209 N.C. 678,184 S.E. 695 (1936).

${ }^{88}$ The opinion-writer disclaimed a repudiation of the rule previously adopted. Such a position seems clearly untenable. 